\title{
The Urban Car Body Design for "Energy Efficient Car Contest 2019" using Quality Function Deployment
}

\author{
Fajrin Nurul Falah ${ }^{1,}$ Gilang Purnama Adi ${ }^{1}$, Cindy Saraswati ${ }^{*}$, Hari Prasetyo ${ }^{1}$, \\ Muchamad Djunaidi' ${ }^{1}$, Ratnanto Fitriadi ${ }^{1}$
}

\begin{abstract}
The Muhammadiyah University of Surakarta team seeks to develop an urban-concept car to participate in the KMHE 2019. The KMHE (Energy Efficient Car Contest) is a competition for students to create safe, economical and environmentally friendly vehicles held by the Ministry of Research, Technology and Higher Education of the Republic of Indonesia. One of the most critical components of a car is the body. The body should be able to protect the driver, and its specifications affect the vehicle's performance. Thus, this research is performed to obtain a sound body design. In designing the body, a three-dimensional visual design modeling using Solidworks 2016 is performed. The specifications of the body are following the KMHE regulations. Afterwards, mass calculation and flow simulation are performed to evaluate the performance of the design. The results are the total body mass is $38.35 \mathrm{~kg}$, and the airflow on the body surface is dominated by laminar flow.
\end{abstract}

Keywords: Design body, fluid flow simulation, KMHE, Solidworks 2016, urban-concept car.

\section{Introduction}

Transportation is significantly related to human life, as a tool in carrying out activities such as travelling from one place to another. It is beneficial to human, especially as a mean of mobility [1]. The definition of transportation is facilities in the form of goods or services available for public [2]. The existence of transportation in a region also reflects how developed the region is [3]. It is one of the essential pillars of a country because of the relatively high level of use [4]. In addition to that, it has a vital role in increasing tourism and economy [5].

Transportation requires energy that may be obtained from several sources, such as fossils [6]. Fuel, which is produced from fossils, is widely used to supply most of the modes of transport in the world [7]. Coal is also made from fossils. It, for example, is widely used as a source of energy in a Steam Power Plant [8]. Fossils are non-renewable energy sources. It affects energy scarcity because most of the energy for worldwide transportation is supplied by fuel from fossil [9].

Another problem is the rising of emission of greenhouse gases from the fuel combustion process in the engine [10]. Excessive energy use will cause energy scarcity so that energy prices become higher [11]. Shortage of energy sources and worsening environmental conditions inspire people to shift to electric cars [12].

1 Faculty of Engineering, Industrial Engineering Department, Muhammadiyah University of Surakarta. Лl. Ahmad Yani, Pabelan, Kartasura, Surakarta 57162 Indonesia.

Email: saraswaticindy43@gmail.com

* Corresponding author
More people use electric vehicles powered by renewable energy sources such as solar power, will decrease air polution[13].

One of the efforts of the Government of Indonesia in providing solutions to the energy scarcity is the automotive and renewable energy-based competition, namely KMHE (Energy Efficient Car Contest). The competition is held by the Ministry of Research, Technology and Higher Education [14]. This competition is oriented towards reducing the use of non-renewable energy.

There are two types of vehicle contested in the KMHE that are prototype and urban [15]. Physically, the difference between the two types is the number of wheels, the prototype has three and the urban has four. The two types are then categorized further into four classes based on the type and source of driving power. One of the classes is electric cars where the type and source of driving energy are an electric motor and a battery.

The development of technology in Indonesia accelerates toward modernity, including in the transportation sector [16]. In the transportation sector, it is shown by the development of environmentally friendly electric cars. In general, an electric car is defined as a car driven by an electric motor that uses energy from a battery [17]. The electric vehicle is introduced for the first time by Robert Anderson from Scotland in 1832-1839. With the development of the automotive industry, electric cars will take a leading role in the future [18]. Electric cars are more efficient and environmentally friendly because they do not produce emissions that pollute the environment [19]. Electric 
car competitions at university level can foster creativity and enthusiasm for students to develop electric cars for the future [20].

The Muhammadiyah University of Surakarta is a private university. A team of this university plans to design an urban-type electric car to take part in the KMHE 2019 held in Malang. In designing the electric car, it is essential to give attention to several aspects evaluated to decide the winner of KMHE 2019. One of the most critical elements is the body of the car. The body serves as a protective component for the car's interior and the driver from extreme weather, from dangerous foreign objects, a penalty for air resistance and risk of minor or severe accidents [21].

The design of the body should follow the stages of the product design process and the regulations of KMHE 2019. There are six stages of product design [22]: First stage (phase zero): planning. Second stage (phase one): developing a concept. Third stage (phase two): system-level design. Fourth stage (phase three): design detail. Fifth stage (phase four): testing and improvement. Sixth stage (phase five) is the mass production phase.

Among these stages, the design detail is one of the most important and very influential stages. The designer must focus on the specifications and dimensions of the product to maintain product quality.

One of the essential body specifications is the type of fluid flow on the body surface. If the airflow is dominated by turbulent flow, it will resist the car when moving. If it is dominated by laminar flow, it will have an opposite effect. Laminar flow does not restrain the speed of the vehicle [23]. This study is conducted using the QFD (Quality Function Deployment) method to obtain the optimal specifications for the urban-concept car body. The QFD is a technique to design products following the desires of the users with a focus on quality. After the design specifications are obtained, the design is then modeled in twodimensional sketches and three-dimensional design models.

One of the seven product design parameters is a model. The model can be a three-dimensional visual form of the product [24]. One of the software for designing three-dimensional product models is Solidworks 2016 [25]. Solidworks 2016 is CAD (ComputerAided Design) based software that supports the design process of a two-dimensional or three-dimensional model [26]. Solidworks 2016 is also equipped with a fluid flow simulation feature. This feature aims to evaluate the aerodynamics of a design. By using this feature, it is expected that the best body design for this urban-concept car can be achieved.
The previous research presents the aerodynamic analysis of the Antawirya Urban Team's body [27]. The authors compare the fluid flow between the new body and the existing body. There is an improvement in the airflow on the surface of the new body. It is shown that there is not any turbulent flow. This because the shape of the new body follows the direction of the airflow when the car is moving. But, the dimensions of the new body are larger than the existing body so that the body mass is also larger.

This current study aims to produce an optimal urbanconcept car body design following the KMHE 2019 regulations and having a preferable fluid flow on the body surface. The preferable body has the airflow on the surface area dominated by laminar flow.

\section{Methods}

The KMHE Technical Regulation 2018 and the benchmarking of general specifications of the urbanconcept car designed by other universities are used as a basis to define a customer needs matrix. Three experts are then requested to give weight and level of importance for each customer need. Subsequently, technical responses are determined through a group discussion analyzing the results of KMHE 2018 and its regulation and benchmarking with other teams. The relationships between the customer requirements and the technical responses are identified, and the relationship levels are also defined. Symbols and values then are assigned to represent the relationships. Afterwards, interviews with experts in the related fields are conducted to determine the priority of the technical responses.

The next step is to define design characteristics using the house of quality method. In this step, the engineering characteristics are determined. They are used as specifications in designing the body of the urban-concept car. Afterwards, the selection of alternative designs using the morphological map method is performed through a focus group discussion. The selected design is employed to develop a threedimensional model using Solidworks 2016. Fluid simulation on the model is then performed also using Solidworks 2016, and the result is analyzed. The final model is used for producing a prototype. Finally, the research is concluded, and suggestions for future research are identified.

\section{Results and Discussions}

\section{Data Collection}

The data collected for the design of the urban-concept car body is the KMHE 2018 regulation. The authors only use articles related to urban-concept car body design. 
Table 1. Customer requirements

\begin{tabular}{|c|c|c|c|c|}
\hline 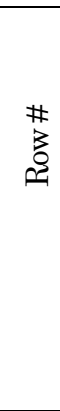 & 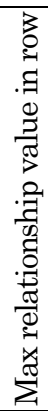 & 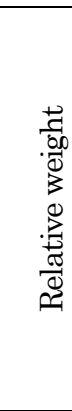 & 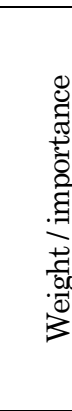 & Customer requirements \\
\hline 1 & 9 & 7.6 & 8.7 & $\begin{array}{l}\text { Windshield shards do not harm the } \\
\text { driver }\end{array}$ \\
\hline 2 & 9 & 6.1 & 7.0 & $\begin{array}{l}\text { There are rearview mirrors with a } \\
\text { minimum size of } 25 \mathrm{~cm} 2\end{array}$ \\
\hline 3 & 9 & 7.0 & 8.0 & $\begin{array}{l}\text { There is ventilation in the steering } \\
\text { room }\end{array}$ \\
\hline 4 & 9 & 7.3 & 8.3 & $\begin{array}{l}\text { There is a partition between the } \\
\text { steering room and the engine room }\end{array}$ \\
\hline 5 & 9 & 7.6 & 8.7 & $\begin{array}{l}\text { Body dimensions following to } \\
\text { KMHE regulations }\end{array}$ \\
\hline 6 & 9 & 6.1 & 7.0 & Body Covers All Components \\
\hline 7 & 9 & 7.0 & 8.0 & $\begin{array}{l}\text { There is a towing hook at the front } \\
\text { of the body }\end{array}$ \\
\hline 8 & 9 & 8.4 & 9.7 & $\begin{array}{l}\text { There are main lights at the front of } \\
\text { the body }\end{array}$ \\
\hline 9 & 9 & 8.4 & 9.7 & $\begin{array}{l}\text { There are turn signals at the front of } \\
\text { the body }\end{array}$ \\
\hline 10 & 9 & 8.4 & 9.7 & $\begin{array}{l}\text { There are brake lights at the rear of } \\
\text { the body }\end{array}$ \\
\hline 11 & 9 & 8.4 & 9.7 & $\begin{array}{l}\text { There are turn signals at the rear of } \\
\text { the body }\end{array}$ \\
\hline 12 & 9 & 5.2 & 6.0 & Windshield protects from sunlight \\
\hline 13 & 9 & 6.4 & 7.3 & The body is easy to sssembly \\
\hline 14 & 9 & 6.1 & 7.0 & The body has minimal thickness \\
\hline
\end{tabular}

The regulations are used for obtaining consumer needs. After the customer needs have been identified, the next step is to give weight to each customer need. The weighting is performed by three experts in the field of design and design modeling. Each expert gave their opinions and suggestions about the variables in the quality matrix. Each variable is then assigned a different weight and level of importance based on the expert's experience in urban-concept car design. The weight and importance values have a scale between 1 and 10. The more significant the variable, the larger the weight and level of importance. The values given by the three experts are then averaged and the results are presented in Table 1.

\section{Quality Function Deployment}

A product is designed and developed to meet the needs and desires of customers. The product must be made with an emphasis on quality at a competitive cost [27]. The Quality Function Deployment (QFD) is a product development system starting from the product design, manufacturing process to the product reaching the consumers. The QFD method is focused on consumer desires [28].
Table 2. Specification of urban-concept car body design

\begin{tabular}{ll}
\hline Item & Specification \\
\hline $\begin{array}{l}\text { Dimension of the rearview mirror } \\
\text { Dimension of the ventilation of the }\end{array}$ & $25 \mathrm{~cm}^{\wedge} 2$ \\
steering wheel vents & $10 \mathrm{~cm}$ x $8 \mathrm{~cm}$ \\
Overall height of the vehicle & $1000 \mathrm{~mm}-1300 \mathrm{~mm}$ \\
Overall width of the vehicle & $1200 \mathrm{~mm}-1300 \mathrm{~mm}$ \\
Overall length of vehicle & $2200 \mathrm{~mm}-3500 \mathrm{~mm}$ \\
Front Track width & $>1000 \mathrm{~mm}$ \\
Back Track width & $>800 \mathrm{~mm}$ \\
Steering wheel dimensions & Height $>1200 \mathrm{~mm}$ \\
& Width $>1200 \mathrm{~mm}$ \\
Ground clearance & $>100 \mathrm{~mm}$ \\
Total mass of vehicle & $<225 \mathrm{~kg}$ \\
Door dimensions & $500 \mathrm{~mm} \times 800 \mathrm{~mm}$ \\
Dimensions of luggage space & $500 \times 400 \times 200 \mathrm{~mm}$ \\
Load capacity of towing hook & $>2000 \mathrm{~N}$ \\
Dimension of steering & $>250 \mathrm{~mm}$ \\
Turning radius & $6000 \mathrm{~mm}$ \\
Wheel diameter & $15-17 \mathrm{inch}$ \\
Body thickness & $2 \mathrm{~mm}$ \\
\hline
\end{tabular}

\section{Customer Requirement}

The results of the group discussion are used as the customer requirements. The statements of the customer requirements must be easy to understand and do not cause multiple interpretations. Therefore, at the next stage, there will be no difficulty in understanding the customer needs. The results of customer requirements are shown in Figure 1.

\section{Technical Requirement}

The technical requirements are defined by a focus group discussion involving the ECRC (Electric Car Research Center) Team, the PUPS Team. The discussion also uses the result of benchmarking with the Mechatronics Team UMM. In the technical requirements (Figure 1), there are several essential parts, in addition to the variables used as technical responses. Each technical requirement has a target or limit for each variable. Each variable is also assigned with one of the following symbols: "X" meaning better on the target, " $\boldsymbol{\Delta}$ " meaning better to be maximized and " $\nabla "$ meaning better to be minimized.

\section{Design Specification}

The Quality Function Deployment method produces optimal design specifications, i.e. comply with the KMHE regulations. The design specifications for all items are presented in Table 2. They are the basis for the $3 \mathrm{D}$ design modeling process and the manufacturing process for the urban-concept car body.

\section{Morphological Map}

The morphological map is a map formed based on the interpretation of customer needs. The map helps the 


\begin{tabular}{|c|c|c|c|c|c|c|c|c|c|c|c|c|c|c|c|}
\hline & $\mathrm{x}$ & $x$ & $\mathrm{x}$ & $x$ & $\boldsymbol{\nabla}$ & $\mathrm{x}$ & $\nabla$ & $x$ & $\boldsymbol{v}$ & $\boldsymbol{\nabla}$ & $\mathrm{x}$ & $x$ & $\boldsymbol{\nabla}$ & $\mathrm{x}$ & $\boldsymbol{\nabla}$ \\
\hline $\begin{array}{r}\text { Quality Characteristics } \\
\text { (a.k.a. "Technical } \\
\text { Requirements" or } \\
\text { "Hows") }\end{array}$ & 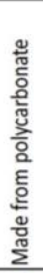 & 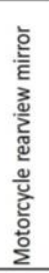 & 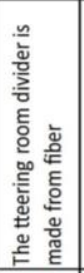 & 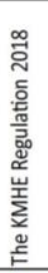 & 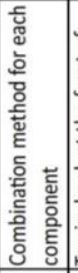 & 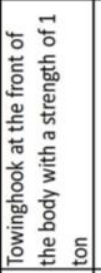 & 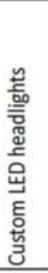 & 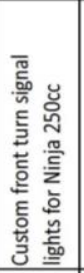 & 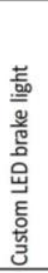 & 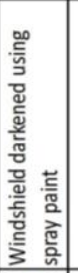 & 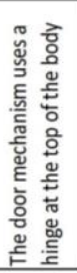 & 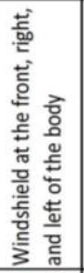 & 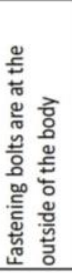 & $\begin{array}{l}\text { 믕 } \\
\text { E⿱ } \\
0 \\
.0 \\
\text { : } \\
\end{array}$ & 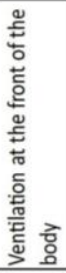 \\
\hline Windshield shards do not harm the driver & $\theta$ & & 0 & $\theta$ & & & & & & $\odot$ & & $\theta$ & & & \\
\hline $\begin{array}{l}\text { There are rearview mirrors with a minimum } \\
\text { size of } 25 \mathrm{~cm} 2\end{array}$ & & $\odot$ & & ○ & o & & & & & & & & & & \\
\hline There is ventilation in the steering room & & & & $\Theta$ & & $\Theta$ & & & & & & & & & $\Theta$ \\
\hline $\begin{array}{l}\text { There is a partition between the steering } \\
\text { room and the engine room }\end{array}$ & & & $\Theta$ & ○ & $\mathrm{o}$ & & & & & & $\Theta$ & & 0 & & \\
\hline $\begin{array}{l}\text { The body dimensions according to the } \\
\text { KMHE regulations }\end{array}$ & 0 & & $\Theta$ & $\odot$ & & & & & & & & $\Theta$ & & $\odot$ & $\odot$ \\
\hline The body covers all components & & & & $\Theta$ & $\boldsymbol{\Delta}$ & $\Delta$ & & & & & & & & 0 & \\
\hline $\begin{array}{l}\text { There is a towing hook at the front of the } \\
\text { body }\end{array}$ & & & & $\Theta$ & $\mathrm{o}$ & $\Theta$ & & & & & & & & & $\mathrm{o}$ \\
\hline $\begin{array}{l}\text { There are main lights at the front of the } \\
\text { body }\end{array}$ & & & & $\odot$ & & & $\odot$ & $\mathrm{o}$ & e & & & & & & \\
\hline $\begin{array}{l}\text { There are turn signals at the front of the } \\
\text { body }\end{array}$ & & & & $\Theta$ & & & $\mathrm{o}$ & $\Theta$ & $\Theta$ & & & & & & \\
\hline $\begin{array}{l}\text { There are brake lights at the rear of the } \\
\text { body }\end{array}$ & & & & $\Theta$ & & & $\Theta$ & $\Theta$ & $\Theta$ & & & & & & \\
\hline $\begin{array}{l}\text { There are turn signals at the rear of the } \\
\text { body }\end{array}$ & & & & $\Theta$ & & & $\Theta$ & $\Theta$ & $\odot$ & & & & & & \\
\hline Windshield for sunlight protection & $\theta$ & & & & & & & & & $\odot$ & & $\mathrm{O}$ & & & \\
\hline The body is easy to assembly & & & & & $\theta$ & & & & & & & & $\theta$ & & \\
\hline The body has minimal thickness & & & $\mathrm{O}$ & & $\mathrm{O}$ & & & & & & & & & 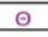 & \\
\hline Target or Limit Value & 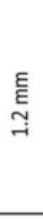 & $\begin{array}{l}\text { 希 } \\
\underset{\Sigma}{\Sigma}\end{array}$ & $\stackrel{\text { E⿱ }}{\sim}$ & $\begin{array}{l}\text { 형 } \\
\text { ه } \\
\text { 을 }\end{array}$ & 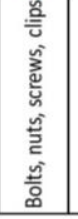 & 蒙 & $\stackrel{\text { 売 }}{\text { N }}$ & 芳 & 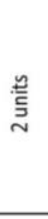 & চั & $\stackrel{\stackrel{\sim}{\nu}}{\sim}$ & 旁 & $\frac{0}{6}$ & $\stackrel{\Xi}{\leftrightarrows}$ & 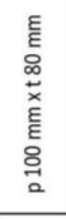 \\
\hline Strong Relationship & & & & & & & & & & & & & & & \\
\hline Moderate Relationship & & & & & & & & & & & & & & & \\
\hline Weak Relationship & & & & & & & & & & & & & & & \\
\hline
\end{tabular}

Figure 1. Technical requirement

process of selecting the best alternative in the process of designing a product [29-30]. This map shows several models to be chosen to find the best solution [31].

The morphological map assists the authors in determining the design concept of the body. Some alternatives models are the winners of the previous KMHE. The concept includes a combination of several needs such as material for the body, windshield type, door type, lamp type, wiper position, and the number of colors. Some alternative models for the UEV-15 TRISULA and the selection process using the morphological map method are shown in Figure 3.

Based on the Morphological Map, one concept from a model is selected for each need. Carbon Fiber Epoxy material is chosen because it is strong and light. The body mass will not be too heavy, and the energy consumption can be minimized. The second requirement is the body shape. The shape of the UMM Mechatronics Team vehicle is chosen. It has an advantage in terms of low air resistance, so the energy consumption is also low. The fourth requirement is the type of door. The selected door opening system is opened upwards, integrated at the top. Thus, the risk of self-closing the door due to hinge movement can be avoided.

The fifth requirement is the type of lamp. An LED light is selected because it is affordable and has good durability. The sixth requirement is the position of the wiper. The desired position is at the top because it is easier to install. The seventh requirement is the number of colors. Four colors are chosen because there is a category for the best design winner. According to the authors, body-color variations will improve the aesthetic of the body. Overall, based on the morphological map method (Figure 2), the following results are obtained:
Material
Body design
Windshield type
Door concept
Lamp type
: Carbon Fiber Epoxy
Wiper position
Number of color 


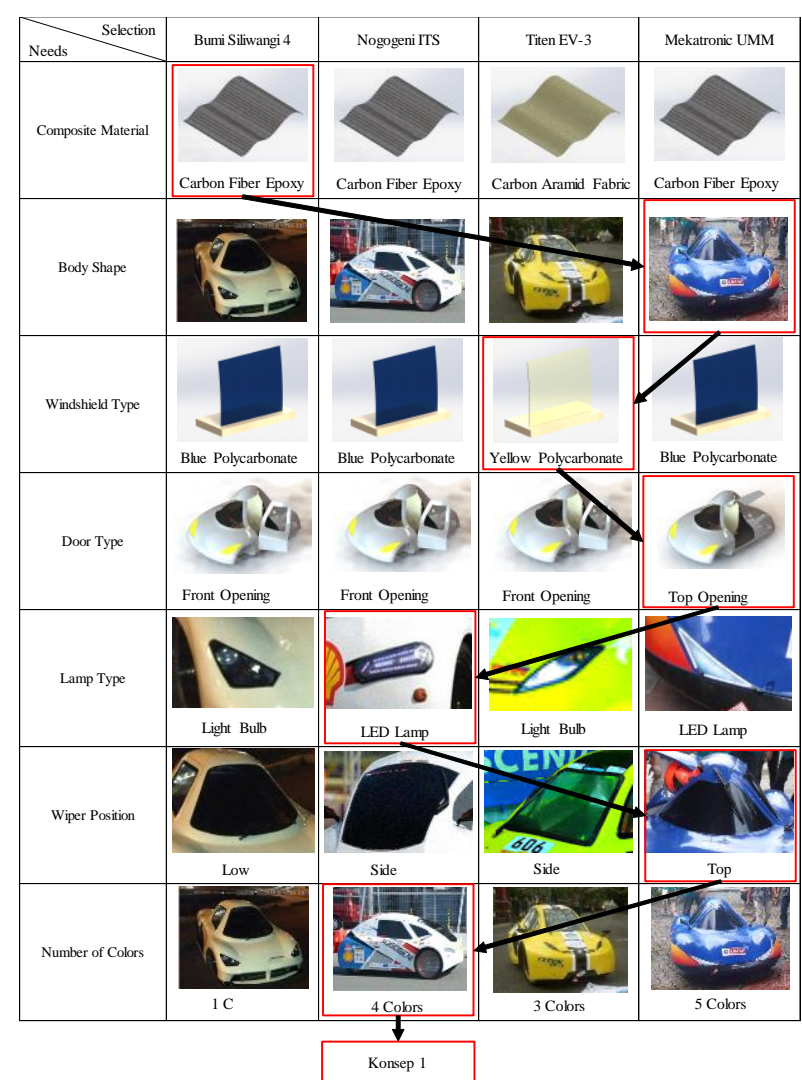

Figure 2. Concept selection process of urban-concept car with the morphological map

\section{Urban-Concept Car Body Design and Simulation}

Based on the concept obtained from the morphological map, the selected material for the body is carbon fiber epoxy composite. The flow simulation is used to evaluate the resistance of the body and to observe the flow pattern. If there is any mismatching the 3D model and the expectation, then a repair stage is carried out to obtain the optimal shape.

\section{Design of Urban-Concept Car Body}

After obtaining the design specifications of the urbanconcept car body, the next step is to design a 3D model. The design of the 3D model uses Solidworks 2016 software with a 1: 1 scale. The design is shown in Figure 3.

\section{Simulation of Urban-Concept Car Body Design}

From the fluid flow simulation, several outcomes are obtained, namely cut plot, surface plot, and flow trajectories. The explanation of each result is as follows:

The cut plot is the first output from the fluid flow simulation, as shown in Figure 4a. There is a blue color on the upper body (number 1) which represents low air resistance. Number 2 indicates the air that is affected when the vehicle accelerates but has low resistance. Number 3 indicates the front body, which experiencing considerable pressure. The shape in that part is made taper to break up the wind that can restrain the vehicle's speed. Number 4 indicates the air that is free from pressure, which is at the bottom and top of the car.

The second output is shown in Figure $4 \mathrm{~b}$. The surface plot displays the same results as the cut plot, but in a three-dimension form. The simulation results are more apparent in this plot. At the front of the car (number 1) there is a slight yellow obstacle because it functions to break the wind. But at the top (number 2 ) and the side (number 3 ) there are no affected parts.

The flow trajectories plot is the third output, as shown in Figure 4c. The flow trajectories display the simulation results in three dimensions along with the direction of fluid flow when the car is moving. It can be observed as pointed by arrow number 1, the wind flow is divided into two paths. The first path passes through the body with a laminar flow pattern that flows perfectly. The second flow enters the interior of the body, as shown by arrow number 2 . The flow entering through the vent has a turbulent pattern. It provides cooling to the interior of the wheelhouse. Arrow number 3 shows the final part of the flow of air passing through the body. As expected, it can be observed a laminar-shaped flow pattern that flows smoothly downwards so that it does not cause a pull.

The objective of the fluid flow simulation is to evaluate how airflow occurs on the body surface. There are two types of fluid flow: laminar (parallel airflow that does not restrain vehicle speed) and turbulent (airflow in an irregular direction and restrains vehicle speed). A sound body vehicle has a laminar fluid flow on the surface of the body. The obstacles that occur become smaller so that the energy consumption decreases. The non-sound body vehicle experiences turbulent fluid flow on the surface. The turbulent flow restrains the speed of the vehicle due to more considerable resistance and thus increases the energy consumption.

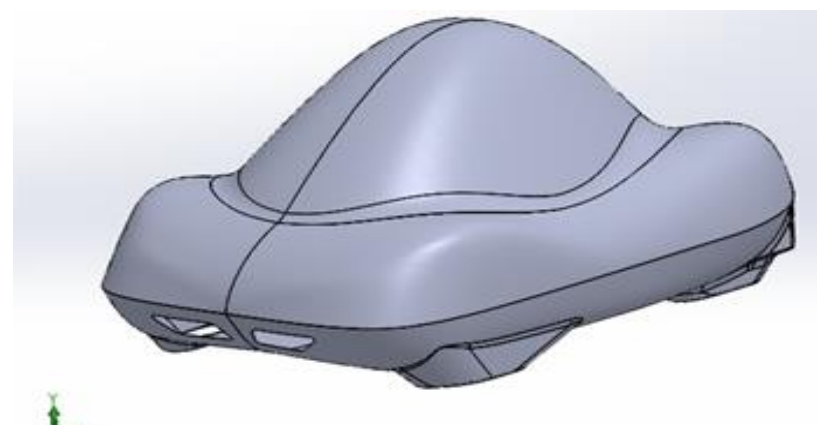

Figure 3. Design of urban-concept car body 


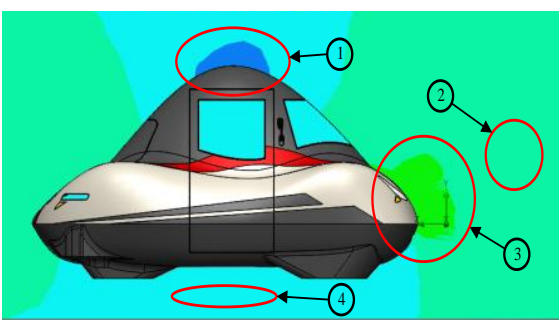

(a)

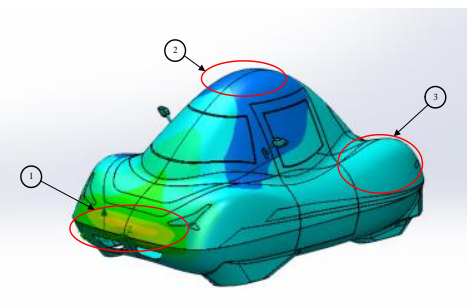

(b)

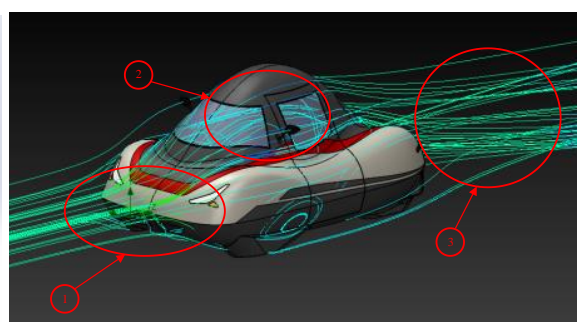

(c)

Figure 4. Result of urban-concept car body design flow simulation

In the fluid flow simulation, especially in Figure 5c, almost all flows that occur are laminar. Turbulent flow occurs only in the interior of the body, at the vents and the lower part of the body in the wheel area. The ventilation is made to circulate air in the wheelhouse, as stated in the regulation. The lower part of the body, in the wheel area, is made perforated (for the wheel). But it is made close to minimize the turbulence in that part. Thus, the body has an exemplary fluid flow, the fluid flow outside of the body is dominated by laminar flow, and turbulent flow only occurs inside of the body.

\section{Conclusion}

The urban-concept car body has been designed to comply with the KMHE regulations. It also has an exemplary fluid flow on the body surface because it is dominated by laminar flow. The results of concept selection with the morphological map are carbon fiber epoxy composite for the body material, polycarbonate windshield, one-hinge on top door, LED lamp, the position of the wiper is at the top, and four paint colors. The total body mass of $38.35 \mathrm{~kg}$ and the most considerable airflow resistance is at the front of the body.

\section{References}

1. Koto, A., and Asnawi, M., Analisis Tingkat Kepuasan Konsumen terhadap Kualitas Jasa Angkutan Bus Trans Metro Pekanbaru. 1, 2016, pp. 83-90, retrieved from http://digilib.mercubuana.ac.id/manager/t!@file_artikel_abstrak/Isi_ Artikel_233515688261.pdf

2. Asmawi, A., Sjoraida, Diah F., and Anwar, Rully K., Masalah dan Dinamika Implementasi Kebijakan Publik tentang Transportasi Kajian di Kota Tasikmalaya, Jawa Barat, Jurnal Ilmu Pengetahuan, 3(2), 2017, pp. 205-218.

3. Dupont, L., Hubert, J., Guidat, C., and Camargo, M., Understanding User Representations, A New Development Path for Supporting Smart City Policy: Evaluation of The Electric Car Use in Lorraine Region, Technological Forecasting and Social Change, 2019, pp. 333 - 346.
4. Oktalihadi, V., and Hidayat, R., Analisis Tingkat Adopsi Teknologi Transportasi Online (Studi Kasus Gojek Padang Tahun 2018), E-Proceeding of Applied Science, 4(3), 2018, pp. 897-904.

5. Truong and Shimizu, The Effect of Transportation on Tourism Promotion: Literature Review on Application of The Computable General Equilibrium (CGE) Model. Department of Tourism Science, Tokyo Metropolitan University, 2016.

6. Ristiana, R., Arief S. R., Ary S. P., dan Carmadi M., Desain Kendali Optimal Konsumsi Energi Pada Sistem Mobil Listrik untuk Model Sistem Linier, Jurnal Telekomunikasi, Elektronika, Komputasi, dan Kontrol, (4) 1, 2018, pp. 1-10.

7. Suryaningrat, M., Pengaruh Penggunaan Biosolar B20 dan Pertamina DEX terhadap Konsumsi Bahan Bakar dan Emisi Gas Buang pada Mesin Diesel 4JA1 Direct Injection, Skripsi Jurusan Teknik Mesin Fakultas Teknik Universitas Negeri Malang, 2019.

8. Kurniawan, D., Analisis Efisiensi Komposisi Bahan Bakar PLTU Batu Bara dengan Menggunakan Bat Algorithm pada PLTU Tanjung Awar-Awar Tuban, Thesis Program Studi Teknik Elektro Universitas Muhammadiyah Gresik, 2019.

9. Braithwaite, D., Soepraptono S., Gatot K. W., Herucokro T., Sugiharto S., Sutadi P. U., Pri A. R., Harga Sebuah Kebijakan Bahan Bakar Fosil: Subsidi Pemerintah Indonesia di Sektor Hulu Minyak \& Gas Bumi. International Institute for Sustainable Development (IISD), 2010, retrieved from https://www.iisd.org/pdf/2010/ffs_awc_indonesia_execbahasa.pdf

10. Karmaker AK, Rahman MM, Hossain MA, Ahmed MR., Exploration and Corrective Measures of Greenhouse Gas Emission from Fossil Fuel Power Stations for Bangladesh, Journal of Cleaner Production 244, 2020, pp. 118645.

11. Mawardi, I., Nurdin, A.., Usman, R., and Abdel HS., Peningkatan Karakteristik Biopellet Kayu Kelapa Sawit sebagai Sumber Energi Alternatif, Proceeding Seminar Nasional Negeri Lhokseumawe, (3) 1, 2019, pp. 230-234.

12. Cao, X., Yang, W., Yao, Y., Electric Car Design Based on Wheel Motor Drive, 7th International Forum on Industrial Design, 2019. 
13. Sutisna, N.A.; Akbar, M.F.A.A., FEM Simulation of Electric Car Chassis Design with Torsional Bar Technology, Journal of Mechanical Engineering and Mechatronics, (3)2, 2018.

14. Thawafani, Lathiifah. Fajrin N.F., Cindy S., Fiki C.S., Hari P., Rancangan Ruang Kemudi Menggunakan Ilmu Ergonomi pada Prototype Mobil Listrik "Ababil", The 8th University Research Colloquium, 2019, pp. 89-96.

15. Regulasi Teknis KMHE 2018, Ministry of Research, Technology and Higher Education of the Republic of Indonesia, 2018.

16. Ramdhanu, Arizky K., AND Supriono, Analisis Persepsi Kemanfaatan, Kemudahan, Kualitas, dan Harga Transportasi Online Sebagai Sarana Penunjang Aksesibilitas Wisatawan di Kota Malang, Jurnal Administrasi Bisnis, 60(2), 2018, pp 64-73.

17. Suhendra, Irfan., R., Angga., and Murtis, Muhammad A., Perancangan dan Implementasi Sistem Pengisian Baterai Otomatis pada Mobil Listrik Berbasis IoT, e-Proceeding of Engineering, 6(2), 2019, pp. 2835.

18. Li, Y. and Zhu, Hui., A Research on Electric Car Styling Design and Low Aerodynamic Drag, 7th International Forum on Industrial Design, 2019,

19. Wilberforce, T., El-Hassan, Z., Khatib, F. N., Al Makky, A., Baroutaji, A., Carton, J. G., and Olabi, A. G., Developments of Electric Cars and Fuel Cell Hydrogen Electric Cars, International Journal of Hydrogen Energy, 42(40), 2017, pp. 25695-25734.

20. Wicaksono, D.A., Korelasi Konstanta Kontrol Proportional Integral Derivative terhadap Kinerja Mobil Listrik Universitas Jember, Skripsi Program Studi Teknik Elektro Fakultas Teknik Universitas Jember, 2015.

21. Mardji, A., dan Prasetyo, D., Aerodynamics Analysis of Electric Car UM Body Surface Using Computational Fluid Dynamics, MATEC Web of Conferences 204, 2018.
22. Ulrich, K. T. dan Eppinger, S. D., Product Design and Development, 5th Edition. New York: McGraw-Hill Education, 2012.

23. Jhon S, Joshua S., and Utomo, T. S., Analisis Aerodinamika Body Mobil Hemat Energi Antawirya Residual-Sat dengan Mengunakan Metode Computational Fluid Dynamics, Jurnal Teknik Mesin, S01, 5(1), 2017, pp. 50-59.

24. Kotler, P., Manajemen Pemasaran Analisis Perencanaan Implementasi dan Kontrol. Jilid 1, Jakarta, PT. Prehalindo, 1997.

25. Hendrawan, M. Alfatih., Perancangan Chassis Mobil Listrik Prototype "Ababil" dan Simulasi Pembebanan Statik dengan Menggunakan Solidworks Premium 2016, The 7th University Research Colloquium, 2018.

26. PT. ARISMA DATA SETIA, Solidworks Flow Simulation, 2018.

27. Rosyidi, C. N.,_Model Penentuan Nilai Target Functional Requirement Berbasis Utilitas, Jurnal Teknik Industri, 14(1), 2012, pp. 35-42.

28. Widodo, I.J., Perencanaan dan Pengembangan Produk: Product Planning and Design. Yogyakarta: UII Press Yogyakarta, 2003.

29. Widodo, L, Silvi A., Fajar A. K., Perancangan Stasiun Kerja Ergonomis pada Stasiun Kerja Printing CV. Karya Mitra Lestari, Jurnal Ilmiah Teknik Industri, 6(1), 2018, pp. 29 - 34.

30. Falah, F.N, Adi, G.P., Saraswati, C., Prasetyo, H., and Djunaidi, M., Penetapan Spesifikasi Desain Body Composite Untuk Urban Concept Berdasarkan Regulasi Kontes Mobil Hemat Energi 2018 menggunakan Metode Quality Function Deployment (QFD), The 9th University Research Colloquium, 2020, pp. 1-7.

31. Cross, N., Engineering Design Methods, Strategies for Product Design. John Wiley \& Sons Ltd, Baffins Lane, Chichester, West Sussex PO19 IUD, England, 1994. 